\title{
RAZVOJ KOMUNIKACIJSKIH FUNKCIJA U DJECE DOBI 1.5-4.0 GODINE
}

\author{
NADINA BOŽIĆ ${ }^{1}$, MAJA CEPANEC ${ }^{2}$ \\ ${ }^{1}$ Doctus, d.o.o., Split, ${ }^{2}$ Laboratorij za istraživanje dječje komunikacije, Odsjek za logopediju, Edukacijsko \\ rehabilitacijski fakultet, Sveučilište u Zagrebu, kontakt: maja.cepanec@erf.unizg.hr
}

Primljeno: 10.10 .2019 .

Izvorni znanstveni rad

Prihvaćeno: 30.04 .2020$.

$81 ` 232-053.4$

doi: $10.31299 /$ hrri.56.1.3

Sažetak: Pragmatičko znanje važan je aspekt komunikacijske kompetencije. Ono obuhvaća komunikacijske funkcije koje osoba upotrebljava i pravila za uporabu tih funkcija na društveno prihvatljiv način. Istraživanja djece tipičnog razvoja potvrđuju pojavu širokog raspona komunikacijskih funkcija već u ranoj dobi, no ne postoji jasan i općeprihvaćeni obrazac razvoja komunikacijskih funkcija u djece starije od 18 mjeseci. Stoga je cilj ovog rada bio ispitati redoslijed i vrijeme pojavljivanja kasnih komunikacijskih funkcija kao što su funkcija traženja informacija, komentiranja, ostvarivanja humora i pripovijedanja. Istraživanjem su obuhvaćeni podaci o 134 djece tipičnog razvoja dobi 18-47 mjeseci prikupljeni nestandardiziranom inačicom upitnika Language Use Inventory (LUI-Hrvatski).

Rezultati su pokazali kako i nakon 18. mjeseca sustavno dolazi do širenja komunikacijskih funkcija te da, porastom dobi, djeca komunikaciju ostvaruju na sve složeniji, apstraktniji i kreativniji način. Osim što se usložnjavaju, rane se funkcije u kasnijoj dobi ostvaruju i kroz sve naprednije komunikacijske forme. Djeca isprva komuniciraju o predmetima $i$ vlastitim aktivnostima (18-23 mjeseca), zatim počinju komunicirati o vlastitoj perspektivi (što dijete misli, voli ili želi) i tuđim aktivnostima (24-29 mjeseci), zatim o tuđoj perspektivi (što druga osoba želi ili voli), nepoznatim riječima i iskazima drugih osoba (30-35 mjeseci) i na kraju o mislima drugih osoba $i$ (socijalnim) pravilima (36-47 mjeseci). Sličan razvojni napredak uočava se $i$ u obilježjima humora (koji se isprva ostvaruje neverbalno a kasnije i verbalno) i pripovijedanja. Razvojne komunikacijske promjene i njihova kvaliteta sugeriraju da se one u velikoj mjeri oslanjaju na razvoj sociokognitivnih (teorija uma) i jezičnih sposobnosti.

Ključne riječi: Language Use Inventory (LUI-Hrvatski), pragmatičke sposobnosti, komunikacijski razvoj, kasne komunikacijske funkcije

\section{UVOD}

Čovjek je prosocijalno biće koje je od samih početaka svojega života usmjereno na socijalne signale i socijalnu okolinu (za pregled v. Grossmann i Johnson, 2007). Interakcija i komunikacija s drugima predstavljaju osnovu ljudskog funkcioniranja i jedan su od temelja dječjeg razvoja.

Pragmatičke teorije jezičnog usvajanja ističu važnost komunikacijskih funkcija kao važnih pokretača jezičnog razvoja (Budwig, 1995; Laakso, Poikkeus, Katajamäki i Lyytinenn, 1999). Djeca počinju komunicirati za široki raspon funkcija već tijekom predjezičnog razdoblja, a kasnije te iste komunikacijske funkcije počinju ostvarivati uporabom riječi (Wetherby, Cain, Yonclas i Walker, 1988). Smatra se da upravo komunikacijske funkcije čine važnu pokretačku snagu usvajanja novih riječi i gramatičkih oznaka (engl. pragmatic bootstrapping) (Snow, 1999).

Djeca počinju aktivno slati poruke drugim osobama (razdoblje namjerne komunikacije) prije negoli što progovore, prosječno u dobi od 9 mjeseci (Bates, Camaioni i Volterra, 1975; Harding i Golinkoff, 1979). Od samih početaka namjerne komunikacije dojenčad komunicira za veći broj komunikacijskih funkcija. Carpenter, Mastergeorge i Coggins još su 1983. godine u longitudinalnom istraživanju djece dobi 8-15 mjeseci zabilježili da u tom ranom razdoblju djeca komuniciraju s funkcijama protestiranja/odbijanja, zahtijevanja radnje, zahtijevanja predmeta, komentiranja radnje, komentiranja predmeta i odgovaranja.

Istraživači komunikacijskih funkcija, posebice oni koji su istraživali i komunikacijske namjere 
djece u predjezičnom razvoju, razvijali su različite klasifikacije koje su odgovarale ciljevima njihovih istraživanja. Čini se da je prvi izazov u opisivanju komunikacijskih funkcija kako ih kategorizirati. Osim toga istraživanja komunikacijskih funkcija nisu česta u odnosu na druge aspekte komunikacijskog razvoja. Zbog svega navedenog ne postoji jedna univerzalna i općeprihvaćena podjela komunikacijskih funkcija. Pregledom literature može se zapaziti doista velik broj različitih klasifikacija koje se uvelike razlikuju ne samo po sadržaju već i po broju kategorija (za kraći pregled v. Wetherby i sur., 1988). Primjerice, Bates i suradnice (1975) su komunikacijske činove djece podijelile u dvije glavne kategorije (imperativne i deklarativne funkcije), Bruner (1981) u tri kategorije, dok ih neke druge klasifikacije dijele u osam (Coggins i Carpenter, 1981), devet (Dore, 1975), dvanaest (Wetherby i sur, 1988) ili čak petnaest kategorija (Wetherby, 1986). Ovo je jedan od razloga zašto su istraživanja o komunikacijskim funkcijama djece ponekad teško usporediva.

Razvoj ranih komunikacijskih funkcija (onih koje se u djece tipičnog razvoja javljaju u dobi do $18 \mathrm{mjeseci}$ ) relativno je dobro opisan (Bates i sur., 1975; Carpenter i sur., 1983; Wetherby i sur., 1988; Carpenter, Nagell i Tomasello, 1998; Crais, Douglas i Campbell, 2004; Beuker, Rommelse, Donders i Buitelaar, 2013), no kasnije promjene u komunikacijskim funkcijama znatno su manje poznate. Važno je napomenuti da postojanje određene funkcije u ranoj dobi (u djece mlađe od 18 mjeseci) ne daje informacije o njezinoj zastupljenosti u ukupnom broju komunikacijskih činova. Također rane komunikacijske funkcije dijete nastavlja koristiti i nakon 18. mjeseca, ali ih s porastom dobi upotrebljava na kompetentniji, fleksibilniji i složeniji način.

Kasnije komunikacijske funkcije pokazatelji su naprednijih razina komunikacijskog ponašanja. To su uglavnom funkcije koje se vežu uz uporabu jezika za različite svrhe i sve uspješnije vođenje razgovora. One odražavaju sve zrelije komunikacijske vještine, ali su i odraz općeg kognitivnog napretka koji omogućava sve složenije i apstraktnije komuniciranje o različitim temama, u različitim situacijama i s različitim osobama. Kategorizacija kasnih komunikacijskih funkcija još je neujednačenija od kategorizacije ranih (npr. Paul, 2007; Haslett, 1983), no kasnim se komunikacijskim funkcijama općenito smatraju funkcija komentiranja, funkcija traženja informacija, funkcije diskursa i funkcija ostvarivanja humora. Funkcija komentiranja javlja se rano (Carpenter, Mastergeorge i Coggins, 1983) i dominantna je komunikacijska funkcija u cijelom ranom i predškolskom periodu (Wetherby i sur., 1988; Jović, 2019), no teme djetetovih komentara mijenjaju se i usložnjavaju od komunikacije o radnjama, preko komunikacije o predmetima, do kompetentne komunikacije o ljudima, događajima i apstraktnim sadržajima.

Funkcija traženja informacija može se pratiti proučavanjem miljokaza razvoja dječjih pitanja. Putanja razvoja upitnih oblika promatra se kroz dimenziju dobi u kojoj se dječja pitanja javljaju, ali i kroz perspektivu pragmatičke funkcije za koju ih dijete upotrebljava.

Funkcijama diskursa smatraju se funkcije razgovora i pripovijedanja. To su vještine koje zahtijevaju istovremenu primjenu apstraktnog razmišljanja, teoriju uma i prilagodbu jezika socijalnoj situaciji. Zbog toga se njihovo pojavljivanje očekuje nešto kasnije. Razgovor se u svojem prvotnom obliku odvija uz vodstvo odrasle osobe. Između druge i treće godine dijete postaje sposobno prilagoditi komunikaciju, sudjelovati u dužim dijalozima i kompetentno koristiti konverzacijske popravke (Lanza i Flahive, 2008). Vještina pripovijedanja još je zahtjevnija od samog sudjelovanja u razgovoru jer dijete tijekom samostalnog pripovijedanja nema pomoć kontekstualnih ključeva te mora posjedovati znanja o oblikovanju vlastitih misli u rečenice koje zatim treba povezati u koherentnu cjelinu. Funkcija pripovijedanja javlja se u svom jednostavnom obliku oko druge godine života. Tada pripovijedanje više nalikuje konverzaciji jer dijete iznosi događaje jedan za drugim, bez međusobne povezanosti. Pripovijedanje se u svojoj složenijoj formi javlja iza četvrte godine. Tada je dijete sposobno pripovijedati s više detalja, pravilno označavati likove i povezati događaje prema pravilnom vremenskom slijedu (McCabe i Peterson, 1991).

Još složenijom funkcijom od funkcije pripovijedanja smatra se funkcija ostvarivanja humora. Naime kompetentna proizvodnja humora podrazumijeva istovremenu primjenu svih dotad usvo- 
jenih pragmatičkih znanja kao što je poznavanje konteksta, razumijevanje skrivenih značenja te primjenu određene doze imaginativnosti i kreativnosti. Iako se prvi znaci humora javljaju već kroz djetetovo imitiranje tuđeg zadirkivanja u dobi od 14 mjeseci, humor u svom pravom obliku dijete pokazuje proizvodnjom samostalno osmišljenih šala u dobi nakon četvrte godine života (Hoicka i Akhtar, 2012).

Razvoj kasnih komunikacijskih funkcija, kao i cjelokupnih komunikacijskih obilježja povezan je, između ostaloga, i s razvojem sociokognitivnih sposobnosti, posebice teorije uma. Teorija uma odnosi se na sposobnost djeteta da razumije vlastita i tuđa mentalna stanja. Kritičnim razdobljem za razvoj ove sposobnosti smatra se period od treće do pete godine života (Wellman, Cross i Watson, 2001). Iako se razvijaju svaka zasebno, komunikacijska namjera, združena pažnja i teorija uma osnova su kompetentne komunikacije o ljudima i s ljudima.

Kvalitetu složene komunikacije dodatno određuju i djetetove mogućnosti da komunikaciju koristi na društveno prihvatljiv način, odnosno njegove pragmatičke sposobnosti. Pragmatičke sposobnosti brojni autori ponekad gotovo poistovjećuju s komunikacijskom ili socijalnom kompetencijom (npr. Prutting, 1982), odnosno smatraju da one obuhvaćaju brojna znanja i sposobnosti važne za primjerenu i učinkovitu komunikaciju, kako verbalnu tako i neverbalnu. Pragmatičko znanje, između ostaloga, čine i komunikacijske funkcije kojima se osoba služi i pravila pod kojima se komunikacijske funkcije upotrebljavaju.

Praćenjem putanje razvoja kasnih komunikacijskih funkcija može se steći uvid u dinamiku i složenost kako komunikacijskog tako i većeg broja drugih razvojnih područja. Komunikaciju nije moguće promatrati kao izoliranu vještinu jer je njezin napredak određen složenim međuodnosom općih kognitivnih, sociokognitivnih i jezičnih sposobnosti (Koyama, 1991; Tomasello, 1995).

\section{CILJ ISTRAŽIVANJA}

Komunikacijske funkcije koje dijete upotrebljava daju uvid u putanju djetetova razvoja te mogu služiti kao vrijedni pokazatelji odstupanja od tipič- nog komunikacijskog razvoja. S obzirom na to da u literaturi postoji manjak istraživanja čiji predmet interesa predstavlja ciljano područje komunikacijskih funkcija (posebice onih kasnih), cilj je ovog istraživačkog rada utvrđivanje redoslijeda kojim se komunikacijske funkcije pojavljuju u djece tipičnog razvoja u dobi od 18 do 47 mjeseci života.

Problemska su pitanja koja će se nastojati razriješiti sljedeća:

Kakav je redoslijed (obrazac) pojavljivanja kasnih komunikacijskih funkcija?

U kojoj se dobi javljaju pojedini oblici kasnih komunikacijskih funkcija?

\section{METODOLOGIJA}

\section{Sudionici}

Istraživanje je temeljeno na prigodnom uzorku roditelja djece u dobi od 18 do 47 mjeseci. Obuhvaćalo je 134 sudionika iz četiri županije Republike Hrvatske: 90 iz Splitsko-dalmatinske županije, 30 iz Dubrovačko-neretvanske, osam iz Varaždinske i šest s područja Grada Zagreba. Roditelji (93\% čine majke) su putem upitnika izvještavali o komunikacijskim obilježjima svoje djece, a u uzorku su podjednako bili zastupljeni dječaci $(\mathrm{N}=63)$ i djevojčice $(\mathrm{N}=71 ; 52,9 \%)$.

Kriteriji za sudjelovanje bili su sljedeći: a) dob djeteta od 18 do 47 mjeseci; b) nepostojanje sumnje na razvojna odstupanja ni utvrđena razvojna odstupanja; c) hrvatski je djetetu materinski, prvi i dominantni jezik.

U svrhu analize podataka sudionici su podijeljeni u pet podskupina s obzirom na dob izraženu u mjesecima (Tablica 1).

\section{Mjerni instrument}

Za potrebe ovog istraživanja korištena je nestandardizirana hrvatska inačica upitnika Language Use Inventory (O’Neill, 2009) koja nosi naziv LUIHrvatski (Ljestvica za procjenu uporabe jezika; prijevod Marta Jovanović, 2016). Kako bi korištenje ove inačice bilo moguće, dobivena je dozvola same autorice upitnika i Knowledge in Development Inc (licenca 1. stupnja) za uporabu ove inačice upitnika $\mathrm{u}$ istraživačke svrhe. 
Tablica 1. Podaci o dobi, dobnim skupinama, spolu i broju djece uključene u istraživanje.

\begin{tabular}{|l|c|c|c|c|c|c|}
\hline oznaka skupine & dob u mjesecima & broj djece $(\mathbf{N})$ & dječaci & djevojčice & prosječna dob & SD \\
\hline $\mathbf{1}$ & $18-23$ & 26 & 13 & 13 & 19,9 & 1,7 \\
\hline $\mathbf{2}$ & $24-29$ & 25 & 14 & 11 & 26,7 & 1,8 \\
\hline $\mathbf{3}$ & $30-35$ & 27 & 10 & 17 & 32,0 & 1,9 \\
\hline $\mathbf{4}$ & $36-41$ & 29 & 10 & 19 & 39,0 & 1,7 \\
\hline $\mathbf{5}$ & $42-47$ & 27 & 16 & 11 & 44,1 & 1,5 \\
\hline Ukupno: & 134 & 63 & 71 & 32,5 & 8,7 \\
\hline
\end{tabular}

Tablica 2. Struktura i sadržaj korištenih podljestvica iz Ljestvice za procjenu uporabe jezika.

\begin{tabular}{|l|l|l|l|}
\hline podljestvica & što ispituje & $\begin{array}{l}\text { struktura } \\
\text { podljestvice }\end{array}$ & primjer čestice \\
\hline O stvarima & $\begin{array}{l}\text { korištenje jezika za komentiranje i } \\
\text { postavljanje pitanja o stvarima (npr. što, } \\
\text { gdje, čije je nešto) }\end{array}$ & $\begin{array}{l}\text { dihotomna skala } \\
\text { (9 čestica) }\end{array}$ & $\begin{array}{l}\text { Komentira li Vaše dijete ili postavlja } \\
\text { pitanja o tome zašto se nešto dogodilo? }\end{array}$ \\
\hline O ljudima & $\begin{array}{l}\text { korištenje jezika za komentiranje i } \\
\text { postavljanje pitanja o ljudima }\end{array}$ & $\begin{array}{l}\text { dihotomna skala } \\
\text { (32 čestice) } \\
\text { Skala Likertova tipa } \\
\text { (4 čestice) }\end{array}$ & $\begin{array}{l}\text { Komentira li Vaše dijete ili postavlja } \\
\text { pitanja o tome što drugi vole ili ne vole? }\end{array}$ \\
\hline Kroz aktivnosti & $\begin{array}{l}\text { korištenje jezika u komunikaciji s } \\
\text { drugima s ciljem utjecaja na tuđe } \\
\text { ponašanje }\end{array}$ & $\begin{array}{l}\text { dihotomna skala } \\
\text { (14 čestica) }\end{array}$ & $\begin{array}{l}\text { Govori li Vaše dijete drugima što da rade } \\
\text { u igri? }\end{array}$ \\
\hline Humor & $\begin{array}{l}\text { korištenje verbalnih i neverbalnih } \\
\text { sredstava za izražavanje humora }\end{array}$ & $\begin{array}{l}\text { dihotomna skala } \\
\text { (5 čestica) }\end{array}$ & $\begin{array}{l}\text { Zadirkuje li dijete druge nazivajući ih } \\
\text { smiješnim imenima? }\end{array}$ \\
\hline $\begin{array}{l}\text { Interesi za } \\
\text { jezik }\end{array}$ & $\begin{array}{l}\text { zainteresiranost za jezik u različitim } \\
\text { životnim situacijama }\end{array}$ & $\begin{array}{l}\text { dihotomna skala } \\
\text { (12 čestica) }\end{array}$ & $\begin{array}{l}\text { Jeste li primijetili da Vaše dijete pita za } \\
\text { značenje novih ili nepoznatih riječi? }\end{array}$ \\
\hline $\begin{array}{l}\text { Prilagođavanje } \\
\text { drugima }\end{array}$ & $\begin{array}{l}\text { način na koji dijete prilagođava razgovor } \\
\text { drugim osobama }\end{array}$ & $\begin{array}{l}\text { dihotomna skala } \\
\text { (15 čestica) }\end{array}$ & $\begin{array}{l}\text { Ako Vaše dijete ne razumije nešto što ste } \\
\text { mu rekli, kaže li uglavnom nešto poput } \\
\text { Molim?, Što? ili Śto si rekao? da bi Vas } \\
\text { bolje razumjelo? }\end{array}$ \\
\hline $\begin{array}{l}\text { Proizvodnja } \\
\text { rečenica i priča }\end{array}$ & $\begin{array}{l}\text { struktura i sadržaj jezične proizvodnje } \\
\text { Lada Vam dijete ispriča priču ili dio priče, } \\
\text { razumijete li tko su likovi u toj priči? }\end{array}$ \\
\hline
\end{tabular}

LUI je mjerni instrument vrlo dobrih psihometrijskih obilježja (O’Neill, 2007) namijenjen probiru odstupanja u pragmatičkim vještinama djece u dobi od 18 do 47 mjeseci. Sastoji se od 14 podljestvica, a za ovo istraživanje, u skladu $\mathrm{s}$ njegovim ciljem ispitivanja komunikacijskih funkcija verbalne komunikacije, odabrane su čestice iz sedam podljestvica (v. Tablicu 2). Tako u istraživanju primjerice nisu korištene podljestvice koje se odnose na uporabu gesta, vrste riječi koje dijete upotrebljava, djetetove interese i sl. Dodatno rezultati na česticama prikazani su samo deskriptivno kroz postotak djece određene dobi koja pokazuju određeno ponašanje, a ne kao rezultat na ljestvici. Roditelji su ljestvicu popunjavali samostalno. Prosječno vrijeme koje je potrebno za popunjavanje cijele ljestvice iznosi od 20 do 30 minuta.

\section{Prikupljanje podataka}

Podaci su prikupljani u trajanju od četiri mjeseca. Nakon što su pronađena djeca koja zadovoljavaju sve preduvjete za ulazak u istraživanje, odgojitelji su roditeljima te djece ponudili mogućnost sudjelovanja u istraživanju. Roditelji su prije popunjavanja upitnika upoznati s ciljem istraživanja, te obaviješteni o dobrovoljnosti i anonimnosti sudjelovanja. Istraživanje je provedeno uz suglasnost ravnatelja ustanova. Roditelji su upitnike popunjavali samostalno, uz mogućnost kontaktiranja istraživača ukoliko se za to pokaže potreba.

\section{Obrada podataka}

Obrada podataka provodila se u statističkom programu IBM SPSS Statistics 21. Podaci su ana- 
lizirani na razini deskriptivne statistike, a rezultati su prikazani grafički i tablično.

Kako bi se dobio jasan uvid u redoslijed i dob pojavljivanja kasnih komunikacijskih funkcija, u obradu su uvrštene odabrane čestice iz sljedećih podljestvica: Kako Vaše dijete komentira $i$ postavlja pitanja o stvarima (O stvarima)?; Kako Vaše dijete komentira i postavlja pitanja o sebi $i$ drugim osobama (O ljudima)?; Kako Vaše dijete upotrebljava riječi u komunikaciji s drugima kroz aktivnosti (Kroz aktivnosti)?; Zadirkivanje $i$ humor Vašeg djeteta (Humor); Zainteresiranost Vašeg djeteta za riječi i jezik (Interesi za jezik); Kako Vaše dijete prilagođava razgovor drugim osobama (Prilagođavanje drugima)?; Kako Vaše dijete proizvodi duže rečenice i priče (Proizvodnja rečenica i priča)?.

Struktura i sadržaj korištenih podljestvica prikazani su u Tablici 2.

\section{REZULTATI I RASPRAVA}

\section{Komentiranje i traženje informacija}

Komentiranje i traženje informacija kao rane socijalne komunikacijske funkcije izrazito su dominantne u svakodnevnoj komunikaciji, a razvojne promjene opažaju se kako u komunikacijskim sredstvima kojima se one ostvaruju (što nije tema ovog istraživanja) tako i u samoj temi komunikacije. Podaci pokazuju da se ove funkcije isprva ostvaruju kroz komunikaciju o predmetima, a tek nešto kasnije, u dobi od dvije godine, može se uočiti da sve više djece komunicira o drugim osobama (Tablica
3). Ovaj podatak u skladu je s ranijim istraživanjima koja potvrđuju da dvogodišnjaci sve češće koriste komunikaciju kako bi sudjelovali u socijalnim interakcijama kao ravnopravni komunikacijski partneri, a sve manje samo s ciljem zadovoljavanja vlastitih potreba (Wertherby i sur., 1988).

Dodatno ovi podaci pokazuju koliko je komentiranje rano prisutno u komunikaciji, čak i razdoblju kad djeca posjeduju vrlo oskudan ekspresivni vokabular.

\section{Komentiranje i traženje informacija o predmetima}

Rezultati pokazuju da djeca u vrlo ranoj dobi počinju komunicirati o svima aspektima neživoga što se može pratiti analizom funkcija za koje koriste komunikaciju kroz pitanja i komentare koje upućuju drugima (vidi Tablicu 4). Razvojno se prvo javljaju komentari i pitanja o identitetu (Što je nešto?) i o posvojnosti (Čije je nešto?). Ove su komunikacijske funkcije u većine djece (više od 50\% ispitanog uzorka) prisutne već prije drugog rođendana (skupina djece dobi 18-23 mj.). Repertoar komentara i pitanja proširuje se već sa navršavanjem druge godine života kada dijete počinje komentirati i tražiti informacije o lokaciji predmeta (Gdje je nešto?) i o uzrocima nekog događaja (Zašto se nešto dogodilo?). Važno je primijetiti da se javljanje ovih komunikacijskih funkcija ne smije poistovjetiti s usvajanjem prikladnih jezičnih struktura (primjerice formulacija pitanja). Navedene komunikacijske funkcije javljaju se nešto ranije od pojave ispravno jezično oblikovanih pitanja o

Tablica 3. Prikaz raspodjele rezultata na podljestvici Komentiranje i traženje informacija. Osjenčana polja prikazuju da je navedena funkcija prisutna u više od polovine djece te dobi.

\begin{tabular}{|l|c|c|c|c|c|}
\hline čestica & $\mathbf{1 8 - 2 3} \mathbf{~ m j}$. & $\mathbf{2 4 - 2 9} \mathbf{~ m j .}$ & $\mathbf{3 0 - 3 5} \mathbf{~ j j}$. & $\mathbf{3 6 - 4 1} \mathbf{~ m j .}$ & $\mathbf{4 2 - 4 7} \mathbf{~ m j}$. \\
\hline komentari i pitanja o predmetima & $50 \%$ & $96 \%$ & $88 \%$ & $100 \%$ & $100 \%$ \\
\hline komentari i pitanja o ljudima & $31 \%$ & $84 \%$ & $88 \%$ & $100 \%$ & $100 \%$ \\
\hline
\end{tabular}

Tablica 4. Prikaz raspodjele rezultata na pojedinim česticama podljestvice Komentiranje i traženje informacija o neživom. Osjenčana polja prikazuju da je navedena funkcija prisutna u više od polovine djece te dobi.

\begin{tabular}{|l|c|c|c|c|c|}
\hline čestica & $\mathbf{1 8 - 2 3} \mathbf{~ m j}$. & $\mathbf{2 4 - 2 9} \mathbf{~ m j .}$ & $\mathbf{3 0 - 3 5} \mathbf{~ m j}$. & $\mathbf{3 6 - 4 1} \mathbf{~ m j}$. & $\mathbf{4 2 - 4 7} \mathbf{~ m j}$. \\
\hline Čije je nešto? & $60 \%$ & $90 \%$ & $96 \%$ & $100 \%$ & $100 \%$ \\
\hline Što je nešto? & $\mathbf{5 2 \%}$ & $\mathbf{8 5 \%}$ & $92 \%$ & $100 \%$ & $100 \%$ \\
\hline Gdje je nešto? & $44 \%$ & $86 \%$ & $96 \%$ & $100 \%$ & $100 \%$ \\
\hline Zašto se nešto dogodilo? & $\mathbf{1 6 \%}$ & $62 \%$ & $72 \%$ & $86 \%$ & $100 \%$ \\
\hline
\end{tabular}


posvojnosti i uzroku, koji se, u prosjeku, očekuju početkom treće godine (Stromswold, 1995).

\section{Komentiranje i traženje informacija o ljudima}

Rezultati dobiveni na podljestvici koja ispituje način na koji djeca komuniciraju o živom, odnosno o ljudima (Tablica 5), mogu se promatrati i tumačiti iz perspektive napretka $u$ istovremeno sazrijevajućem sociokognitivnom razvoju. Uvidom u podatke jasno je vidljiv način na koji napredak u kognitivnim sposobnostima djetetu otvara mogućnost prema kompetentnijoj komunikaciji. Naime s 18 mjeseci dijete je sposobno verbalno izraziti ono što se trenutačno događa u njegovoj neposrednoj okolini (što druga osoba radi, gdje se dijete nalazi i sl.). Ono komunicira o fizičkom, odnosno o onome za što mu ne treba mentalni otklon od situacije koja se događa ovdje i sada. Drugi fenomen koji se može primijetiti jest da dijete preko otkrivanja vlastitih misli, želja i osjećaja (komentari i pitanja o tome u većine su djece prisutne u dobi od 24 do 29 mjeseci) polako počinje shvaćati i perspektivu drugih (pojava takvih komentara i pitanja u dobi 30-35 mjeseci). Tuđa mentalna stanja postepeno postaju predmet djetetove komunikacije nakon 30 . mjeseca života. Ovaj podatak pokazuje kako djetetovo "otkrivanje" tuđih mentalnih stanja tijekom treće godine života postupno dovodi do značajnih razvojnih promjena u teoriji uma koje se bilježe od treće do pete godine (Wellman i sur., 2001). Sociokognitivno složena funkcija komentiranja i postavljanja pitanja o tome što druge osobe misle javlja se tek u četvrtoj godini života. Podaci ovog istraživanja dodatno dokazuju da je djetetov napredak u sposobnostima pripisivanja mentalnih sta- nja sebi i drugima vrlo vjerojatno važan preduvjet kompetentne komunikacije o ljudima (Tomasello, 1995).

\section{Komunikacija tijekom zajedničke igre}

Rezultati dobiveni česticama koje ispituju način i predmet djetetove komunikacije tijekom zajedničkih aktivnosti (Tablica 6) daju podatak o tome da se isprva zapažaju neposredne imitacije tuđih iskaza. To je očekivano ako se uzme u obzir činjenica da je razvoj komunikacije i jezika u ranim fazama razvoja poduprt uvježbavanjem ponavljanja onoga što djeca čuju u svojoj okolini (Meltzhoff, 1988). Proučavanjem teme dječje komunikacije tijekom aktivnosti može se ponovno uočiti tendencija prvotnog komuniciranja o fizičkom, to jest o radnjama. Također opet je jasno vidljiv napredak od komunikacije o sebi do kasnije kompetentne komunikacije o tuđim radnjama. Važnim korakom, do kojeg dolazi nakon 30. mjeseca života, smatra se pojava metajezičnih sposobnosti. Naime dijete u toj dobi počinje pokazivati interes za jezik, odnosno time potvrđuje da sve više razmišlja o samoj strukturi i značenju verbalnog sredstva kojim se služi. U toj dobi se uočavaju i sposobnosti "popravljanja" komunikacijskih činova, odnosno funkcija traženja pojašnjenja. Također tijekom istog razvojnog perioda dijete radi odmak od trenutne situacije što je vidljivo kroz sve češću pojavu komunikacije o igrama i crtanim filmovima, odnosno sve se više javljaju komentari o samom sadržaju, a ne fizičkim osobinama, za što je potrebno postojanje sposobnosti korištenja metakognitivnih vještina. Još složeniji korak u razvoju komunikacije predstavlja početak komunikacije o pravilima, do kojeg dolazi

Tablica 5. Prikaz raspodjele rezultata na pojedinim česticama podljestvice Komentiranje i traženje informacija o ljudima. Osjenčana polja prikazuju da je navedena funkcija prisutna u više od polovine djece te dobi.

\begin{tabular}{|l|c|c|c|c|c|}
\hline Čestica & $\mathbf{1 8 - 2 3 . \mathbf { m j }}$ & $\mathbf{2 4 - 2 9} \mathbf{~ m j}$. & $\mathbf{3 0 - 3 5} \mathbf{~ m j}$. & $\mathbf{3 6 - 4 1} \mathbf{~ m j}$. & $\mathbf{4 2 - 4 7} \mathbf{~ m j}$ \\
\hline Što druga osoba radi? & $56 \%$ & $96 \%$ & $92 \%$ & $100 \%$ & $100 \%$ \\
\hline Gdje se nalazi dijete? & $53 \%$ & $84 \%$ & $84 \%$ & $100 \%$ & $96 \%$ \\
\hline Gdje se druga osoba nalazi? & $56 \%$ & $96 \%$ & $92 \%$ & $100 \%$ & $100 \%$ \\
\hline Što dijete misli? & $37 \%$ & $92 \%$ & $80 \%$ & $93 \%$ & $96 \%$ \\
\hline Što dijete (ne) želi? & $44 \%$ & $88 \%$ & $92 \%$ & $100 \%$ & $100 \%$ \\
\hline Što dijete (ne) voli? & $12 \%$ & $67 \%$ & $84 \%$ & $97 \%$ & $92 \%$ \\
\hline Što drugi (ne) žele? & $12 \%$ & $44 \%$ & $72 \%$ & $97 \%$ & $92 \%$ \\
\hline Što drugi (ne) vole? & $\mathbf{7 \%}$ & $56 \%$ & $79 \%$ & $97 \%$ & $88 \%$ \\
\hline Što drugi misle o nečemu? & $0 \%$ & $28 \%$ & $48 \%$ & $69 \%$ & $88 \%$ \\
\hline
\end{tabular}


nakon trećeg rođendana. Komunikacija o pravilima podrazumijeva potpuno shvaćanje tuđe perspektive i složenu prilagodbu komunikacije tuđoj razini znanja. Kod trogodišnjaka se počinje nazirati i pojava predoperacijske faze kognitivnog razvoja prema Piagetu koja se javlja kada je dijete sposobno koristiti mentalne reprezentacije i simboličko razmišljanje. Slično se može utvrditi i pojavom komentara o tome što su drugi rekli, odnosno o činjenicama koje su iznijeli.

\section{Funkcija ostvarivanja humora}

Podaci prikazani u Tablici 7 potvrđuju činjenicu da je humor aktivnost koja se zbog svoje složenosti javlja razvojno nešto kasnije. Razlog je tomu činjenica da ostvarivanje humora podrazumijeva usklađenu upotrebu viših mentalnih sposobnosti (McGhee, 1974; Hoicka i Akhtar, 2012).

Dijete isprva u dobi od 18 mjeseci zadirkuje neverbalnim sredstvima, i to najčešće potpunom imitacijom ponašanja odrasle osobe, kao i namjernim izvođenjem pojedinih ponašanja na zadirkujući način (primjerice umeće slagalice na pogrešna mjesta iako je roditelj svjestan da je dijete zna ispravno sastaviti). Zatim je kod dvogodišnjaka uočena pojava ostvarivanja humora jednostavnim verbalnim načinima (primjerice dijete kaže pogrešnu riječ ili namjerno izgovori riječ na smiješan način iščekujući reakciju okoline). Tek u četvrtoj godini dijete je sposobno istovremeno i kompetentno koristiti kognitivne, socijalne i jezične sposobnosti što potvrđuje činjenica da dijete te dobi počinje stvarati vlastite šale (stvara smiješne rime i smiješna imena). Pričanje viceva i šala posljednja je "stepenica" razvoja humora u ovom razdoblju, te se značajnije razvija tek u petoj godini života. Ovi rezultati uglavnom su usklađeni s rezultatima ranijih istraživanja (za pregled v. Airenti, 2016).

\section{Funkcija pripovijedanja}

Rezultati dobiveni na podljestvici koja daje informacije o razvoju komunikacijskih funkcija pripovijedanja (Tablica 8) potvrđuju činjenicu da su izvještavanje i pripovijedanje sposobnosti koje se kod djece pojavljuju nešto kasnije u odnosu na druge komunikacijske funkcije.

Tomu u prilog ide podatak dobiven ovim istraživanjem iz kojeg je vidljivo da se označavanje likova u (poznatoj) priči u većine djece javlja tek u trećoj godini života, kada dijete također poči-

Tablica 6. Prikaz raspodjele rezultata na pojedinim česticama podljestvica Komunikacija tijekom zajedničkih aktivnosti, Zainteresiranost djeteta za riječi i jezik i Prilagodba komunikacije drugim osobama. Osjenčana polja prikazuju da je navedena funkcija prisutna u više od polovine djece te dobi.

\begin{tabular}{|l|c|c|c|c|c|}
\hline Čestica & $\mathbf{1 8 - 2 3} \mathbf{~ m j .}$ & $\mathbf{2 4 - 2 9} \mathbf{~ m j}$. & $\mathbf{3 0 - 3 5} \mathbf{~ j}$. & $\mathbf{3 6 - 4 1} \mathbf{~ m j . ~}$ & $\mathbf{4 2 - 4 7} \mathbf{~ m j}$. \\
\hline Ponavlja tuđi iskaz. & $\mathbf{5 9 \%}$ & $96 \%$ & $92 \%$ & $83 \%$ & $92 \%$ \\
\hline Opisuje što ono radi. & $47 \%$ & $88 \%$ & $76 \%$ & $79 \%$ & $81 \%$ \\
\hline Opisuje što drugi rade. & $35 \%$ & $64 \%$ & $84 \%$ & $86 \%$ & $96 \%$ \\
\hline Pita za značenje nepoznatih riječi. & $12 \%$ & $36 \%$ & $84 \%$ & $83 \%$ & $92 \%$ \\
\hline Komunicira o igrama i crtanim filmovima. & $18 \%$ & $33 \%$ & $60 \%$ & $79 \%$ & $81 \%$ \\
\hline Traži pojašnjenje. & $12 \%$ & $24 \%$ & $56 \%$ & $83 \%$ & $100 \%$ \\
\hline Komentira što su drugi rekli. & $12 \%$ & $28 \%$ & $56 \%$ & $90 \%$ & $96 \%$ \\
\hline Komunicira o pravilima. & $0 \%$ & $17 \%$ & $40 \%$ & $72 \%$ & $81 \%$ \\
\hline
\end{tabular}

Tablica 7. Prikaz raspodjele rezultata na odabranim česticama podljestvice Zadirkivanje i humor. Osjenčana polja prikazuju da je navedena funkcija prisutna u više od polovine djece te dobi.

\begin{tabular}{|l|c|c|c|c|c|}
\hline Čestica & $\mathbf{1 8 - 2 3} \mathbf{~ m j .}$ & $\mathbf{2 4 - 2 9} \mathbf{~ m j .}$ & $\mathbf{3 0 - 3 5} \mathbf{~} \mathbf{j}$. & $\mathbf{3 6 - 4 1} \mathbf{~ m j .}$ & $\mathbf{4 2 - 4 7} \mathbf{~ m j}$. \\
\hline Radi nešto pogrešno na zadirkujući način. & $53 \%$ & $52 \%$ & $64 \%$ & $65 \%$ & $73 \%$ \\
\hline Kaže nešto pogrešno na smiješan način. & $29 \%$ & $52 \%$ & $72 \%$ & $86 \%$ & $89 \%$ \\
\hline stvaranje smiješne rime & $0 \%$ & $4 \%$ & $32 \%$ & $52 \%$ & $58 \%$ \\
\hline Zadirkuje druge nazivajući ih smiješnim imenima. & $6 \%$ & $20 \%$ & $20 \%$ & $62 \%$ & $69 \%$ \\
\hline Priča viceve ili šale. & $0 \%$ & $8 \%$ & $24 \%$ & $41 \%$ & $42 \%$ \\
\hline
\end{tabular}


nje iznositi niz događaja iz poznate priče. Nakon otprilike pola godine isti ti događaji počinju biti i smisleno povezani. Važno je napomenuti da izne- sene podatke treba uzeti s dozom opreza jer se sve navedene sposobnosti, prema literaturi, očekuju nešto kasnije. Primjerice McCabe i Petterson

Tablica 8. Prikaz raspodjele rezultata na odabranim česticama podljestvice Proizvodnja dužih rečenica i priča. Osjenčana polja prikazuju da je navedena funkcija prisutna u više od polovine djece te dobi.

\begin{tabular}{|l|l|c|c|c|c|c|}
\hline & Čestica & $\mathbf{1 8 - 2 3} \mathbf{~ m j}$. & $\mathbf{2 4 - 2 9} \mathbf{~ m j}$. & $\mathbf{3 0 - 3 5} \mathbf{~ m j}$. & $\mathbf{3 6 - 4 1} \mathbf{~ m j}$. & $\mathbf{4 2 - 4 7} \mathbf{~ m j}$. \\
\hline \multirow{3}{*}{ poznata priča } & označavanje likova u priči & $31 \%$ & $72 \%$ & $92 \%$ & $96 \%$ & $100 \%$ \\
\cline { 2 - 7 } & niz događaja & $25 \%$ & $68 \%$ & $88 \%$ & $96 \%$ & $96 \%$ \\
\cline { 2 - 7 } & smisleno povezani događaji & $19 \%$ & $44 \%$ & $76 \%$ & $89 \%$ & $92 \%$ \\
\hline $\begin{array}{l}\text { vlastito } \\
\text { iskustvo }\end{array}$ & $\begin{array}{l}\text { spontano i smisleno izvještavanje o } \\
\text { događaju }\end{array}$ & $0 \%$ & $9 \%$ & $21 \%$ & $36 \%$ & $34 \%$ \\
\hline
\end{tabular}

\begin{tabular}{|c|c|c|c|}
\hline & $\begin{array}{l}\text { Nizanje događaja } \\
\text { u priči } \\
\text { Označavanje likova } \\
\text { u priči }\end{array}$ & $\begin{array}{l}\text { Smisleno povezivanje } \\
\text { događaja u priči }\end{array}$ & $\begin{array}{l}\text {--> Jasno prepričavanje } \\
\text { vlastitih iskustava }\end{array}$ \\
\hline $\begin{array}{l}\text { Neverbalno } \\
\text { zadirkivanje }\end{array}$ & $\begin{array}{l}\text { Verbalno zadirkivanje } \\
\text { (pogrešno imenovanje) }\end{array}$ & $\begin{array}{l}\text { Verbalno zadirkivanje } \\
\text { (stvaranje smiješnih } \\
\text { rima, smišljanje } \\
\text { smiješnih imena) }\end{array}$ & --> Pričanje viceva i šala \\
\hline
\end{tabular}

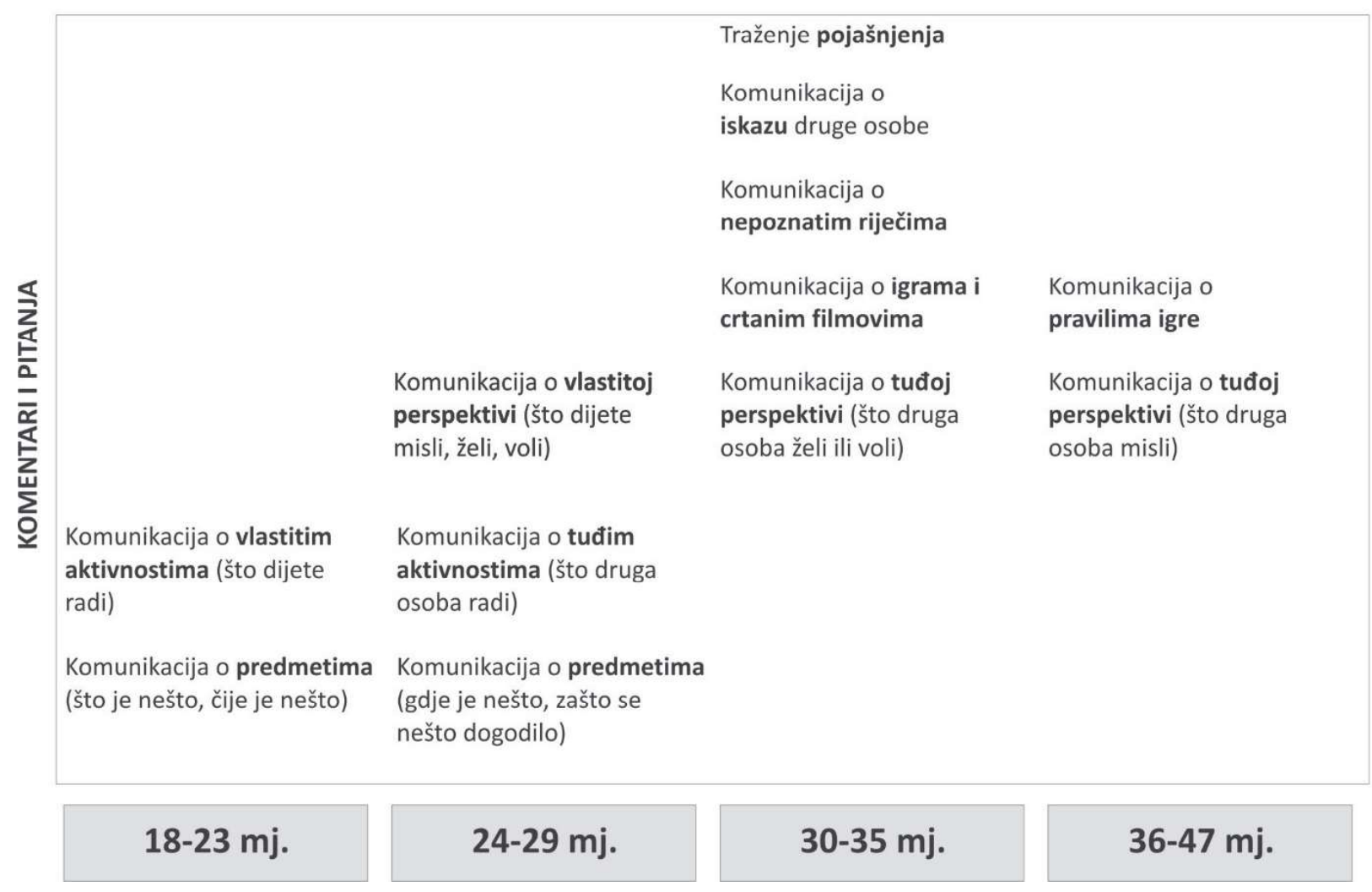

Slika 1. Usložnjavanje komunikacijskih funkcija u djece dobi 1.5-4 godine. Sposobnosti u prikazu naznačene su u onoj dobi kada je navedena sposobnost uočena u većine djece (> 50\%) te dobi. Sivom bojom označene su vještine koje su tek u nastajanju u dobi 36-47 mjeseci. 
(1991) iznose da se pravilno označavanje likova i korištenje smislenog redoslijeda događaja javlja tek između treće i četvrte godine. Treba uzeti u obzir činjenicu da su miljokazi dobiveni ovim istraživanjem proizišli iz subjektivnih procjena roditelja. Također čestice same po sebi ne daju informaciju o tome koliko je djetetovo pripovijedanje samostalno, a koliko je pod vodstvom odrasle osobe, kao ni koliko se učestalo javljaju pogreške u navedenim sposobnostima. Svu složenost pripovijedanja pokazuje činjenica da djeca relativno kasno (prema izvješću roditelja tek u petoj godini života) mogu samostalno prepričati niz događaja koji su im se dogodili tijekom dana (primjerice prepričati posjet zoološkom vrtu). Ove informacije pokazuju da dijete uvježbava pripovijedanje kroz model jednostavnih i poznatih priča, uz veći broj ponavljanja i, vrlo često, vizualnu podršku (primjerice slikovnicu), te da su nezrele naznake pripovijedanja prisutne $\mathrm{u}$ ranoj dobi, ali da se navedena funkcija razvija kroz dulje razdoblje. Odmak koji je potreban za sagledavanje vlastitih iskustava, jezično oblikovanje iskaza i sociokognitivna komponenta nužna za izdvajanje komunikacijskome partneru važnih situacija i predstavljanje svega toga na drugome jasan i smislen način očito zahtijeva istodobno sazrijevanje većeg broja temeljnih sposobnosti djeteta.

\section{Razvojni pregled pojave kasnijih komunikacijskih funkcija}

Pregledom svih rezultata koji su proizišli iz ovog istraživanja moguće je zaključiti, to jest potvrditi, postojanje izrazite dinamike ranog komunikacijskog razvoja, odnosno razvoja kasnih komunikacijskih funkcija u djece starije od 18 mjeseci. Sažimanjem svih prikupljenih i iznesenih podataka može se jasno sagledati razvojna ekspanzija komunikacijskih funkcija djeteta, pomak od komunikacije o fizičkome i predmetima prema komunikaciji o ljudima te usvajanje sve složenijih i apstraktnijih aspekata ljudske komunikacije (Slika 1).

Funkcija komentiranja prisutna je već u dobi od 18 mjeseci i u dobi od dvije godine uočava se široki raspon tema djetetovih komentara. Komentiranje i traženje informacija o neživome prethodi komentiranju i traženju informacija o ljudima. Funkcije traženja pojašnjenja te komentiranja tuđih iskaza javlja se krajem treće godine života, istodobno kad se opaža verbalno zadirkivanje i smisleno povezivanje događaja u priči. Početkom četvrte godine opaža se pojava komuniciranja o apstraktnim pravilima i mislima drugih osoba.

$\mathrm{Na}$ temelju podataka poznatih iz literature i kvalitativne analize prikazanih razvojnih promjena može se zaključiti da kvaliteta razvoja komunikacijskih funkcija i njihove složenosti ukazuje na to da je njihov razvoj visoko povezan s razvojem općih kognitivnih, sociokognitivnih i jezičnih sposobnosti. Zbog toga se svako razdoblje ranog komunikacijskog razvoja može tumačiti i napretkom u drugim područjima razvoja koji su preduvjet ili posljedica istovremenog napretka u komunikacijskim sposobnostima.

\section{ZAKLJUČAK}

Izrazito je važno uočiti kontinuitet razvoja komunikacijskih funkcija i sveukupnu nadogradnju komunikacijskih funkcija od jednostavne komunikacije o fizičkome, preko razvoja komunikacije o apstraktnome, kao i razvoju funkcija humora i pripovijedanja. Kasnije komunikacijske funkcije nadograđuju se na rane funkcije, odnosno dijete s porastom dobi postojeće komunikacijske funkcije koristi na složeniji i konvencionalniji način te se njihova kvaliteta mijenja. Poznavanje te razvojne dinamike jako je važno iz perspektive razumijevanja tipičnog razvoja, ali i iz perspektive kliničkog, dijagnostičkog i terapijskog rada. Naime podaci iz ovog istraživanja mogu poslužiti kao grubi pokazatelji miljokaza kasnijeg komunikacijskog razvoja. Također ovi podaci mogu poslužiti kao osnova za izradu standardiziranih testova za procjenu pragmatičkog razvoja za hrvatsko govorno područje što je prijeko potrebno ako se u obzir uzme činjenica da je zabilježen porast broja djece s odstupanjima u upotrebi jezika. Osim u dijagnostičke svrhe navedeni podaci mogu se iskoristiti i kao nit vodilja u postavljanju ciljeva intervencije. Navedeno omogućuje sustavnost i sveobuhvatnost kliničkog rada.

\section{ZAHVALA}

Autorice zahvaljuju Marti Jovanović na ustupanju prikupljenih podataka (upitnika) koji su činili dio uzorka ovog istraživanja. 


\section{LITERATURA}

Airenti, G. (2016). Playing with expectations: A contextual view of humor development. Frontiers in Psychology, 7, članak 1392. doi: 10.3389/fpsyg.2016.01392

Bates, E., Camaioni, L., Volterra, V. (1975). The acquisition of performatives prior to speech. Merrill-Palmer Quarterly of Behavior and Development, 21(3), 205-226.

Beuker, K.T., Rommelse, N.N.J., Donders, R., Buitelaar, J.K. (2013). Development of early communication skills in the first two years of life. Infant Behavior \& Development, 36, 71-83. doi: 10.1016/j.infbeh.2012.11.001

Bruner, J. (1981). Early social interaction and language acquisition. Language and Communication, 1, 155-178.

Budwig, N. (1995). A developmental functionalist approach to child language. Mahwah, NJ: Erlbaum.

Carpenter, R.L., Mastergeorge, A.M., Coggins, T.E. (1983). The aquistion of communicative intentions in infants eight to fifteen months of age. Language and Speech, 26, 101-116. doi: 10.1177/002383098302600201

Carpenter, M., Nagell, K., Tomasello, M. (1998). Social cognition, joint attention, and communicative competence from 9 to 15 months of age. Monographs of the Society for Research in Child Development, 63(4), X-142. doi: $10.2307 / 1166214$

Coggins, T.E., Carpenter, R.L. (1981). The communicative intention inventory: a system for observing and coding children`s early intentional communication. Applied Psycholinguistics, 2, 235-251. doi: 10.1017/ S0142716400006536

Crais, E., Douglas, D., Campbell, C. (2004). The intersection of the development of gestures and intentionality. Journal of Speech, Language, and Hearing Research, 47, 678-695. doi: 10.1044/1092-4388(2004/052)

Dore, J. (1975). Holophrases, speech acts and language universals. Journal of Child Language, 2(1), 21-40. doi: $10.1017 / \mathrm{S} 0305000900000878$

Grossmann, T., Johnson, M. H. (2007). The development of the social brain in human infancy. European Journal of Neuroscience, 25(4), 909-919. doi: 10.1111/j.1460-9568.2007.05379.x

Harding, C.G., Golinkoff, R.M. (1979). The origins of intentional vocalizations in prelinguistic infants. Child Development, 50, 33-40. doi: 10.2307/1129038

Haslett, B. J. (1983). Communicative functions and strategies in children's conversations. Human Communication Research, 9(2), 114-129. doi: 10.1111/j.1468-2958.1983.tb00687.x

Hoicka, E., Akhtar, N. (2012). Early humour production. British Journal of Developmental Psychology, 30, 586-603. doi: 10.1111/j.2044-835X.2011.02075.x

Jovanović, M. (2016). Prilagodba Ljestvice za procjenu uporabe jezika i pilot primjena u Hrvatskoj. (Diplomski rad). Edukacijsko-rehabilitacijski fakultet Sveučilišta u Zagrebu, Zagreb.

Jović, M. (2019). Spontana uporaba gesta djece predškolske dobi. (Diplomski rad). Edukacijsko-rehabilitacijski fakultet Sveučilišta u Zagrebu, Zagreb.

Koyama, T. (1991). Study on cognitive prerequisites for actions used in the intentional communication in mentally retarded infants. Japan Journal of Logopedics and Phoniatrics, 32(2), 185-197. doi: 10.5112/jjlp.32.185

Laakso, M.L., Poikkeus, A.M., Katajamäki, J., Lyytinen, P. (1999). Early intentional communication as a predictor of language development in young toddlers. First Language, 19(56), 207-231. doi: 10.1177/014272379901905604

Lanza, J. R., Flahive, L.K. (2008). Guide to Communication Milestones. East Moline: Lingui Systems, Inc.

McCabe, A., Peterson, C. (1991). Developing narrative structure. New Jersey: Lawrence Erlbaum Associates.

McGhee, P. E. (1974). Cognitive mastery and children's humor. Psychological Bulletin, 81(10), 721-730.

Meltzhoff, A. N. (1988). Infant imitation and memory: nine-month-olds in immediate and deferred tests. Child Development, 59(1), 217-225. doi: 10.1111/j.1467-8624.1988.tb03210.x 
O'Neill, D. K. (2007). The Language Use Inventory for Young Children: A parent-report measure of pragmatic language development for 18- to 47-month-old children. Journal of Speech Language and Hearing Research, 50(1), 214. doi: 10.1044/1092-4388(2007/017)

O’Neill, D. K. (2009). Language Use Inventory (LUI) Manual. Waterloo, Ontario: Knowledge in Development, Inc.

Paul, R. (2007). Language disorders from infancy through adolescence: assessment \& intervention (3rd edition). St Oluis: Mosby.

Prutting, C.A. (1982). Pragmatics as social competence. Journal of Speech and Hearing Disorders, 47, 123-143. doi: $10.1044 /$ jshd. 4702.123

Snow, C. E. (1999). Social perspectives on the emergence of language. U: B. MacWhinney (ur.): The emergence of language (str. 257-276). Mahwah, NJ: Erlbaum.

Stromswold, K. (1995). The acquisition of subject and object Wh-questions. Language Acquisition, 4(1-2), 5-48. doi: $10.1080 / 10489223.1995 .9671658$

Tomasello, M. (1995). Joint attention as social cognition. U: C. Moore, P. Dunham (ur.): Joint attention: its origins and role in development (str. 103-130). New York: Psychology Press.

Wellman, H.M., Cross, D., Watson, J. (2001). Meta-analysis of theory-of-mind development: the truth about false belief. Child Development, 72,(3), 655-684. doi: 10.1111/1467-8624.00304

Wetherby, A.M. (1986). Ontogeny of communicative functions in autism. Journal of Autism and Developmental Disorders, 16(3), 295-316. doi: 10.1007/bf01531661

Wetherby, A.M., Cain, D. H., Yonclas, D. G., Walker, V. G. (1988). Analysis of intentional communication of normal children from prelinguistic to the multiword stage. Journal of Speech and Hearing Research, 31(2), 240-252. doi: $10.1044 /$ jshr.3102.240

\section{DEVELOPMENT OF COMMUNICATION FUNCTIONS IN CHILDREN AGED 1.5-4.0 YEARS}

\footnotetext{
Abstract: Pragmatic knowledge is an important aspect of communication competence, which consists of communication functions that a person uses and of the rules on how to use those functions in a socially appropriate way. Studies on typically developing children confirm the occurrence of a large number of communication functions at an early age. However, available data do not provide us with a clear and generally accepted developmental course of communication functions in children older than 18 months. Therefore, the aim of the present study was to gain insight into the order and time of appearance of later communication functions such as seeking information, commenting, developing narrative abilities and being funny. The study used the non-standardised research adaptation of the Language Use Inventory (LUI-Croatian) to collect data on 134 typically developing children aged 18-47 months.

After the age of 18 months, communication functions expanded systematically, and children began to communicate in an increasingly complex, abstract and creative way. Some early appearing communication functions became more complex and involved more advanced communication forms. At first, children communicated about objects and their own activities (18-23 months), then about their own perspective (what they thought, liked or wanted), other people's activities (24-29 months), someone else's perspective (what the other person wanted or liked), unfamiliar words and statements by others (30-35 months) and lastly, other people's thoughts and (social) rules (36-47 months). Developmental progress was also observed in their humor (which was achieved initially nonverbally and later verbally) and storytelling. Developmental communication changes and their quality suggest that they rely heavily on the development of sociocognitive ability (theory of mind) and language ability.
}

Keywords: Language Use Inventory (LUI-Croatian), pragmatic skills, communication development, late communication functions 